\title{
ANALYSIS OF BISPHENOL A IN INDONESIAN CANNED FOOD BY GAS CHROMATOGRAPHY
}

\author{
HERMAN SURYADI*, AMIRATUL HAQ RASYID, HARMITA
}

Laboratory of Pharmaceutical Chemistry, Faculty of Pharmacy, Universitas Indonesia, Depok, 16424, Indonesia. Email: hsuryadi@farmasi.ui.ac.id Received: 02 August 2018, Revised and Accepted: 07 August 2018

\begin{abstract}
Objective: This study aimed to design and optimize a gas chromatography-flame ionization detection (GC-FID) method to determine the bisphenol A (BPA) content in Indonesian canned food samples.

Methods: GC with Hewlett-Packard-1 capillary columns (length, $30 \mathrm{~m}$; inside diameter, $0.25 \mathrm{~mm}$; and film thickness, $0.25 \mu \mathrm{m}$ ) was used with a column temperature of $150^{\circ} \mathrm{C}$ that was programmed to increase by $10^{\circ} \mathrm{C} / \mathrm{min}$ to $260^{\circ} \mathrm{C}$. Injector and detector temperatures were 280 and $300^{\circ} \mathrm{C}$, respectively, the gas flow rate was $1.0 \mathrm{~mL} / \mathrm{min}$, and injection volume was $3.0 \mu \mathrm{L}$. Three types of canned food samples were prepared by ethyl acetate extraction and stored under four different conditions $\left(4-8^{\circ} \mathrm{C}, 25-30^{\circ} \mathrm{C}, 40^{\circ} \mathrm{C}\right.$ for $30 \mathrm{~min}$, and $40^{\circ} \mathrm{C}$ for $\left.60 \mathrm{~min}\right)$ to determine BPA migration levels.

Results: Method validation (system compatibility, selectivity, calibration curve linearity, accuracy, and precision) was acceptable for BPA concentrations ranging from 2 to $15 \mu \mathrm{g} / \mathrm{mL}$, with a coefficient of correlation of 0.99983 . The limits of detection and quantitation were 0.287 and $0.956 \mu \mathrm{g} / \mathrm{mL}$, respectively. Only one canned food sample type (Group A) showed BPA contamination under all storage conditions and exceeded the recommended guidelines for daily ingestion.
\end{abstract}

Conclusion: The optimized GC-FID method was selective and relatively sensitive in the detection and quantitation of BPA. Furthermore, higher storage temperatures and durations increased the level of BPA migration into food.

Keywords: Bisphenol A, Canned foods, Contamination analysis, Gas chromatography-flame ionization detection, Validation.

(C) 2018 The Authors. Published by Innovare Academic Sciences Pvt Ltd. This is an open access article under the CC BY license (http://creativecommons. org/licenses/by/4. 0/) DOI: http://dx.doi.org/10.22159/ijap.2018.v10s1.05

\section{INTRODUCTION}

Bisphenol A (BPA) is a plastic constituent monomer widely used in the production of polycarbonate plastics and epoxy resins since the 1960s. While polycarbonate plastics are used in hard plastic bottles and food storage containers, epoxy resins are used as a protective coating inside metal cans to maintain food and beverage quality by preventing their direct contact with the metal [1]. However, this compound has the potential to disrupt the human endocrine system as BPA compounds mimic and/or inhibit some hormones, especially estrogen [2]. Significant ingestion of BPA has been found to be harmful to the fetus, infants, and young children due to a lack of feedback regulating the activity, synthesis, and removal of certain hormones. Furthermore, BPA has been found to disturb the chromosomal distribution of the ovum in pregnant women, causing genetic changes, and leading to miscarriage and genetic disorders in the fetus, such as Down syndrome [3]

A previous study reported that in certain environmental conditions, containers made of polycarbonate or epoxy resins release BPA compounds which will contaminate food or beverages stored therein. BPA release into packaged foods and beverages is affected by temperature, heating time, and the physicochemical properties of the stored contents $[4,5]$. The daily consumption limit of BPA that can be tolerated by an adult human is equal to $5 \mu \mathrm{g} / \mathrm{kg}$ according to the European Food Safety Authority in 2014; this is a revision of the previous $50 \mu \mathrm{g} / \mathrm{kg}$ limit recommended in 2006. Such a revision suggests that the known risks associated with ingestion of BPA on human health have significantly increased. In addition, Indonesian National Drug and Food Control Agency 2011 regulations on food packaging monitoring established a specific migration limit of $0.6 \mathrm{ppm}$ for polycarbonate resin packaging [1].

base on data from Ministry of Trade of the Republic of Indonesia in 2017, canned/processed food markets for meat, fish/seafood, vegetables, fruits, pasta, and other ready-to-eat foods in Indonesia reached 4.4 tons in 2012 and will increase by $11 \%$ per-year [6]. Considering such a large amount of canned food is consumed in Indonesia, this population has an increased risk of BPA-induced health issues. The present study designed and optimized a gas chromatography (GC) with flame ionization detection (FID) method to determine the BPA content in canned food samples in Indonesia. GC-FID is a sensitive, selective, fast, economical, and simple method for detecting a wide range of organic compounds [7-9]. The results of this study will provide important information on canned food safety and quality in Indonesia.

\section{METHODS}

\section{Optimization of GC-FID analysis conditions}

Optimization of GC-FID analysis conditions began with the determination of an optimal column temperature. A standard BPA solution $(100 \mu \mathrm{g} / \mathrm{mL}$; Sigma-Aldrich) was injected $(3.0 \mu \mathrm{L})$ into a Shimadzu GC-17A GC with chromatography with Hewlett-Packard-1 capillary column (length, $30 \mathrm{~m}$; inside diameter, $0.25 \mathrm{~mm}$; and film thickness, $0.25 \mu \mathrm{m}$ ) with FID detector using two different column temperature methods: (1) Isothermal $\left(250\right.$ and $\left.280^{\circ} \mathrm{C}\right)$ and $(2)$ an initial temperature of $150^{\circ} \mathrm{C}$ programmed to increase by $10^{\circ} \mathrm{C} / \mathrm{min}$ up to $260^{\circ} \mathrm{C}$. Sample volume was optimized by injecting $1.0,2.0$, and $3.0 \mu \mathrm{L}$ of $15-\mathrm{ppm}$ standard BPA solution into the GC-FID using the optimal column temperature. Column temperature and sample volume optimization were done with injector and detector temperatures set at 280 and $300^{\circ} \mathrm{C}$, respectively, and a gas flow rate of $1.0 \mathrm{~mL} / \mathrm{min}$. To optimize the gas flow rate, a standard BPA solution $(15 \mu \mathrm{g} / \mathrm{mL})$ was injected $(3.0 \mu \mathrm{L})$ into the GC-FID using $0.8,1.0$, and $1.2 \mathrm{~mL} / \mathrm{min}$ gas flow rates. The above optimum analysis conditions were assessed based on the separation between two adjacent peaks (resolution), peak sharpness, tailing factor, peak retention time, and column efficiency (number of theoretical plates and height equivalent to the theoretical plate [HETP]). 
System compatibility test

After optimization of analysis conditions, a system compatibility test was conducted. A standard BPA solution $(15 \mu \mathrm{g} / \mathrm{mL})$ was injected $(3.0 \mu \mathrm{L})$ into the GC-FID 6 times under optimal analysis conditions. Injection results were recorded, and repeated values were counted to determine the coefficient of variation (\% CV). Parameters observed were the resolution, peak sharpness, tailing factor, peak retention time, and column efficiency (number of theoretical plates and HETP).

\section{Validation of BPA analysis method by GC-FID}

The BPA analysis method was validated by GC-FID through calibration curve and linearity test. A standard BPA solution $(100 \mu \mathrm{g} / \mathrm{mL})$ was diluted with methanol (Merck) to 2, 4, 6, 8, 10, and $15 \mu \mathrm{g} / \mathrm{mL}$. Then, each concentration was injected $(3.0 \mu \mathrm{L})$ into the GC-FID using optimal analysis conditions. The limits of detection (LOD) and limit of quantitation (LOQ) were determined from the calibration curve The selectivity of the BPA analysis method was tested by preparing BPA and sample matrix solutions, then injecting each $(3.0 \mu \mathrm{L})$ into the GCFID using optimal analysis conditions and observing whether there was interference (in the chromatogram) at the same retention time as the BPA.

The accuracy and precision of the BPA analysis method were assessed by preparing three food samples that had been mixed with $5 \mathrm{~mL}$ of standard BPA; each at $2 \mu \mathrm{g} / \mathrm{mL}, 4 \mu \mathrm{g} / \mathrm{mL}$, and $6 \mu \mathrm{g} / \mathrm{m}$ concentrations. Afterward, BPA extraction from the samples was performed as described below in the sample preparation process. A total of $3.0 \mu \mathrm{L}$ of each solution were injected into the GC-FID using optimal analysis conditions; this test was replicated 6 times.

\section{Food sample preparation}

Samples taken from three types of canned foods obtained from Depok, West Java, and Indonesia, were placed under four different storage treatments. Samples with codes A1, B1, and C1 were stored in a refrigerator at $4-8^{\circ} \mathrm{C} ; \mathrm{A} 2, \mathrm{~B} 2$, and $\mathrm{C} 2$ were stored at room temperature $\left(25-30^{\circ} \mathrm{C}\right) ; \mathrm{A} 3, \mathrm{~B} 3$, and $\mathrm{C} 3$ were stored in an oven at $40^{\circ} \mathrm{C}$ for $30 \mathrm{~min}$; and $\mathrm{A} 4, \mathrm{~B} 4$, and $\mathrm{C} 4$ were stored in an oven at $40^{\circ} \mathrm{C}$ for $60 \mathrm{~min}$. Food samples were homogenized in advance with a homogenizer for $3 \mathrm{~min}$. A 5-g sample of the homogenized food was then extracted with 30 $\mathrm{mL}$ of ethyl acetate (Merck). The ethyl acetate layer was removed and stored in a glass beaker, and the remaining liquid was extracted two more times with $30 \mathrm{~mL}$ of ethyl acetate each; all ethyl acetate layers were combined. Then, the extract was dried in a vaporizer cup above a water bath, redissolved in $5 \mathrm{~mL}$ of methanol, filtered using $0.45-\mu \mathrm{m}$ pore filter paper, and stored in vials before GC-FID analysis. Vials of sample extracts were stored at $4^{\circ} \mathrm{C}$ before analysis. The test solution can be used for analysis by filtering using $0.45 \mu \mathrm{m}$ filter paper. Extracted and filtered samples to be analyzed were each injected $(3.0 \mu \mathrm{L})$ into the GC-FID using the optimized analysis conditions. GC-FID analyses were performed in triplicate for each sample.

\section{RESULTS AND DISCUSSION}

\section{Optimum GC-FID analysis conditions}

Based on the results presented in Table 1, the optimal column temperature for GC-FID analysis of BPA is the programmed temperature method, which begins at $150^{\circ} \mathrm{C}$ and increases $10^{\circ} \mathrm{C} / \mathrm{min}$ up to $260^{\circ} \mathrm{C}$. The BPA chromatogram appeared with a column temperature around $247^{\circ} \mathrm{C}$, which is above the boiling point of BPA $\left(220^{\circ} \mathrm{C}\right)$.
Based on the results presented in Table 2, the optimum analysis volume was $3.0 \mu \mathrm{L}$.

Based on the results presented in Table 3, the optimal gas flow rate for GC-FID analysis of BPA was $1.0 \mathrm{~mL} / \mathrm{min}$ as it was able to reduce retention time, while retaining good peak resolution and column efficiency.

\section{System compatibility test}

Based on the results presented in Table 4, six injections of a $15 \mu \mathrm{g} / \mathrm{mL}$ standard BPA solution produced comparable results with low variation.

\section{Validation of BPA analysis method by GC-FID}

A calibration curve was prepared through injection of various concentrations of the standard BPA solution $(2,4,6,8,10$, and $15 \mu \mathrm{g} / \mathrm{mL})$ into the GC-FID, and the LOD, LOQ and linearity of the regression line were assessed. As shown in Table 5, the calibration curve results were linear. The LOD and LOQ calculated from the equation of the regression line for BPA were 0.287 and $0.956 \mu \mathrm{g} / \mathrm{mL}$, respectively (Table 5)

Chromatograms of standard BPA solution and the sample matrix (Fig. 1) showed that there was little to no interference at the same retention time as BPA, demonstrating the selectivity of the analytical method used.

Calculation of the accuracy of the BPA analysis method through GC-FID resulted in average percent BPA recoveries in samples containing 2, 4, and $6 \mu \mathrm{g} / \mathrm{mL}$ BPA of $102.93 \%, 97.19 \%$, and $94.42 \%$ (Table 6). Calculation of precision showed \% CV values of $3.24 \%, 1.23 \%$, and $0.79 \%$ with standard addition of 2,4 , and $6 \mu \mathrm{g} / \mathrm{mL} \mathrm{BPA}$, respectively (Table 6).

\section{BPA levels in canned food samples}

Only sample Group A was found to be positive for BPA contamination and under all of the storage conditions tested. Table 7 shows that

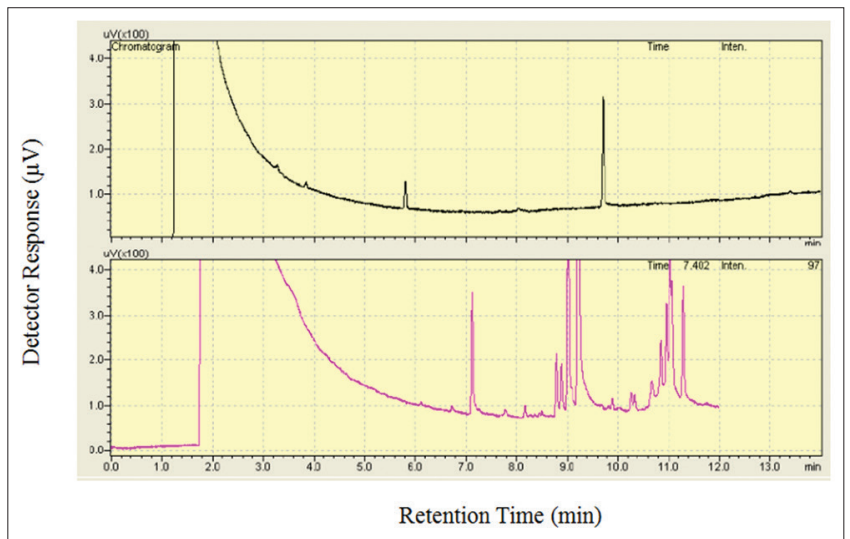

Fig. 1: Gas chromatography-flame ionization detection chromatogram of bisphenol A (BPA) selectivity. Peak retention times of standard BPA solution $(100 \mu \mathrm{g} / \mathrm{mL})$, (a) and sample matrix (b) using optimal analysis conditions including an Hewlett-Packard-1 capillary column (length, $30 \mathrm{~m}$; inside diameter, $0.25 \mathrm{~mm}$; and film thickness, $0.25 \mu \mathrm{m}), 280^{\circ} \mathrm{C}$ injection and $300^{\circ} \mathrm{C}$ detection temperatures, programmed column temperature starting at $150^{\circ} \mathrm{C}$ and increasing $10^{\circ} \mathrm{C} / \mathrm{min}$ to $260^{\circ} \mathrm{C}$ $1.0 \mathrm{~mL} / \mathrm{min}$ carrier gas flow rate, and injection volume of $3.0 \mu \mathrm{L}$

Table 1: Optimization of column temperature using isothermal and programmed temperature methods

\begin{tabular}{llllll}
\hline Temperature method & $\begin{array}{l}\text { Retention } \\
\text { time (min) }\end{array}$ & $\begin{array}{l}\text { Number of } \\
\text { theoretical plates }\end{array}$ & HETP & $\begin{array}{l}\text { Tailing } \\
\text { factor }\end{array}$ & Resolution \\
\hline $250^{\circ} \mathrm{C}$ (isothermal) & - & - & - & - & - \\
$280^{\circ} \mathrm{C}$ (isothermal) & - & - & - & - & - \\
Programmed temperature $^{\dagger}$ & 9.713 & $430,768.914$ & 0.0696 & 1.026 & 185.552 \\
\hline
\end{tabular}

${ }^{+}$The baseline temperature was set at $150^{\circ} \mathrm{C}$ and programmed to increase $10^{\circ} \mathrm{C} / \mathrm{min}$ up to $260^{\circ} \mathrm{C}$. HETP: Height equivalent to the theoretical plate 
Table 2: Optimization of injection volume

\begin{tabular}{llllrr}
\hline $\begin{array}{l}\text { Analysis } \\
\text { volume }(\boldsymbol{\mu L})\end{array}$ & $\begin{array}{l}\text { Retention } \\
\text { time }(\mathbf{m i n})\end{array}$ & $\begin{array}{l}\text { Peak } \\
\text { area }(\boldsymbol{\mu V} / \mathbf{s})\end{array}$ & $\begin{array}{l}\text { Number of } \\
\text { theoretical plates }\end{array}$ & $\begin{array}{l}\text { HeTP } \\
\text { factor }\end{array}$ & $\begin{array}{l}\text { Resolution } \\
1.0\end{array}$ \\
\hline 9.698 & 205.2 & $458,755.709$ & 0.0654 & 1.248 \\
3.0 & 9.704 & 300.4 & $436,567.681$ & 0.0687 & 1.093 \\
\hline
\end{tabular}

HETP: Height equivalent to the theoretical plate

Table 3: Optimization of gas flow rate

\begin{tabular}{lllcc}
\hline $\begin{array}{l}\text { Flow rate } \\
\text { (mL/min) }\end{array}$ & $\begin{array}{l}\text { Retention time } \\
\text { (min) }\end{array}$ & $\begin{array}{l}\text { Number of } \\
\text { theoretical plates }\end{array}$ & HETP & $\begin{array}{c}\text { Tailing } \\
\text { factor }\end{array}$ \\
\hline 0.8 & 10.553 & $530,604.240$ & 0.0565 & 1.073 \\
1.0 & 9.740 & $368,468.159$ & 0.0814 & 1.126 \\
1.2 & 9.407 & $367,281.960$ & 0.0817 & 0.000 \\
\hline
\end{tabular}

Table 4: GC-FID system compatibility with $15 \mu \mathrm{g} / \mathrm{mL}$ BPA solution

\begin{tabular}{llllllr}
\hline $\begin{array}{l}\text { Retention } \\
\text { time (min) }\end{array}$ & $\begin{array}{l}\text { Peak } \\
\text { area }\end{array}$ & SD & \% CV & $\begin{array}{l}\text { Number of } \\
\text { theoretical plates }\end{array}$ & $\begin{array}{c}\text { HETP } \\
\text { Resolution } \\
\text { factor }\end{array}$ \\
\hline 9.7149 .706 & 572.3 & 3.1513 & 0.554 & $366,156.44$ & 0.0819 & 1.367 \\
9.721 & 572.3 & & & $344,506.59$ & 0.0871 & 1.183 \\
9.721 & 564.1 & & $346,577.92$ & 0.0866 & 1.149 \\
9.709 & 567.5 & & $369,028.05$ & 0.0813 & 0.000 \\
9.709 & 568.2 & & & $366,425.84$ & 0.0819 & 0.000 \\
9.706 & 570.0 & & & $414,917.28$ & 0.0723 & 1.154 \\
\hline
\end{tabular}

GC-FID: Gas chromatography-flame ionization detection, SD: Standard deviation, CV: Coefficient of variation, HETP: Height equivalent to the theoretical plate, BPA: Bisphenol A

Table 5: Calibration curve data, LOD, and LOQ of BPA using optimal analysis conditions

\begin{tabular}{llllc}
\hline $\begin{array}{l}\text { Concentration } \\
(\boldsymbol{\mu g} / \mathbf{m L})\end{array}$ & $\begin{array}{l}\text { Peak } \\
\text { area }(\mathbf{y})\end{array}$ & $Y_{\mathrm{i}}$ & $\left(\mathbf{y}-\mathbf{y}_{\mathbf{i}}\right)^{2}$ & $\begin{array}{l}\text { S }(\mathbf{y} / \mathbf{x}) \\
\mathbf{L O D} \\
(\boldsymbol{\mu g} / \mathbf{m L})\end{array}$ \\
\hline 2 & 11 & 7.368 & 13.19142 & 3.9675 \\
4 & 91.1 & 90.338 & 0.580644 & 0.287 \\
6 & 170.5 & 173.308 & 7.884864 & \\
8 & 255.4 & 256.278 & 0.770884 & \\
10 & 334.4 & 339.248 & 23.5031 & \\
15 & 550.8 & 546.673 & 17.03213 & \\
\hline
\end{tabular}

BPA: Bisphenol A, LOD: Limit of detection, LOQ: Limit of quantitation

BPA levels in all of sample Group A significantly exceeded the limit recommended by the Indonesian National Drug and Food Control Agency $(0.6 \mathrm{ppm})$. However, BPA contamination was not detection in sample Groups B or C regardless of storage form.

\section{DISCUSSION}

Considering the large amount of canned food consumed in Indonesia, the population is at an increased risk for BPA-induced health issues. The present study assessed BPA content in a sampling of canned foods in Indonesia by GC-FID to provide information on canned food safety and quality. Overall, the results showed that after optimization of GC-FID analysis conditions and BPA detection methods, only sample Group A was found to have significantly higher levels of BPA contamination under all storage conditions examined than is considered safe by the Indonesian National Drug and Food Control Agency. On the other hand, BPA was not detected in sample Groups B or C regardless of storage condition.

To devise an acceptable GC-FID method by which to analyze BPA content in canned food samples, the GC-FID analysis conditions needed to be optimized. Importantly, the two column temperature optimization methods used were adapted to the boiling point of BPA and necessary to producing the best separation results (i.e., selectively and sensitivity). The injector temperature $\left(280^{\circ} \mathrm{C}\right)$ was set higher than the maximum column temperature so that the entire sample could evaporate as soon as the sample was injected. The detector temperature $\left(300^{\circ} \mathrm{C}\right)$ should be $15-30^{\circ} \mathrm{C}$ higher than the boiling point of the compound being analyzed and adapted to the detector used. For a flame ionization, the detector temperature should be $>100^{\circ} \mathrm{C}$ to prevent water condensation from oxidizing the FID, thereby decreasing its sensitivity [10].

Table 1 shows that the optimal column temperature required for BPA analysis by GC-FID was the programmed, gradually increased temperature method because it produced a better number of theoretical plates, HETP, and resolution than the isothermal methods, which produced superimposed and unclear chromatograms. The programmed temperature method also provided good peak resolution because the temperature rose slowly, allowing the compound peak to appear in accordance with its boiling point, which has a different retention time. Based on the results, the BPA chromatogram appeared with a column temperature around $247^{\circ} \mathrm{C}$, which is above the boiling point of BPA $\left(220^{\circ} \mathrm{C}\right)$.

Next, the injection volume was optimized to improve sensitivity and peak results. The optimal injection volume was $3.0 \mu \mathrm{L}$ for the present study because it had a large peak area and higher resolution compared to other volumes analyzed (Table 2). This indicates that a greater injection volume produces a larger peak area. The final GC-FID parameter 
Table 6: Accuracy and precision of BPA analytical method

\begin{tabular}{|c|c|c|c|c|c|c|c|}
\hline $\begin{array}{l}\text { Standard (BPA) } \\
(\mu \mathrm{g} / \mathrm{mL})\end{array}$ & $\begin{array}{l}\text { Total } \\
\text { peak area }\end{array}$ & $\begin{array}{l}\text { Sample } \\
\text { peak area }\end{array}$ & $\begin{array}{l}\text { Counted level } \\
\text { of BPA }(\mu \mathrm{g} / \mathrm{mL})\end{array}$ & $\begin{array}{l}\text { Average } \\
(\mathrm{BPA})(\mu \mathrm{g} / \mathrm{mL})\end{array}$ & SD & $\% \mathrm{CV}$ & \% UPK \\
\hline \multirow[t]{6}{*}{2} & 32.3 & 23.8 & 2.027 & 2.0585 & 0.07 & 3.24 & 101.35 \\
\hline & 30.1 & & 1.974 & & & & 98.7 \\
\hline & 35.8 & & 2.112 & & & & 105.6 \\
\hline & 32.4 & & 2.030 & & & & 101.5 \\
\hline & 37.4 & & 2.160 & & & & 108.0 \\
\hline & 33.2 & & 2.048 & & & & 102.4 \\
\hline \multirow[t]{6}{*}{4} & 108.1 & 23.8 & 3.855 & 3.887 & 0.05 & 1.23 & 96.36 \\
\hline & 111.7 & & 3.941 & & & & 98.53 \\
\hline & 106.5 & & 3.816 & & & & 95.40 \\
\hline & 109.6 & & 3.891 & & & & 97.27 \\
\hline & 111.5 & & 3.936 & & & & 98.41 \\
\hline & 109.4 & & 3.886 & & & & 97.14 \\
\hline \multirow[t]{6}{*}{6} & 182.3 & 23.8 & 5.643 & 5.666 & 0.04 & 0.79 & 94.05 \\
\hline & 182.6 & & 5.650 & & & & 94.17 \\
\hline & 184.4 & & 5.694 & & & & 94.89 \\
\hline & 183.1 & & 5.662 & & & & 94.37 \\
\hline & 186.2 & & 5.737 & & & & 95.62 \\
\hline & 180.8 & & 5.607 & & & & 93.45 \\
\hline
\end{tabular}

SD: Standard deviation, CV: Coefficient of variation, \% UPK, \% recovery. BPA: Bisphenol A

Table 7: BPA levels determined in canned food sample Group A stored under various conditions

\begin{tabular}{|c|c|c|c|c|c|}
\hline Sample code & Storage form & Peak area & (BPA) $(\mu \mathrm{g} / \mathrm{mL})$ & Average (BPA) $(\mu \mathrm{g} / \mathrm{mL})$ & SD (\%) \\
\hline $\mathrm{A} 1$ & $\begin{array}{l}\text { Refrigerator } \\
\left(4-8^{\circ} \mathrm{C}\right)\end{array}$ & $\begin{array}{l}12.1 \\
17.2 \\
22.9\end{array}$ & $\begin{array}{l}2.114 \\
2.237 \\
2.374\end{array}$ & 2.242 & 0.13 \\
\hline $\mathrm{A} 2$ & $\begin{array}{l}\text { Room temperature } \\
\left(25-30^{\circ} \mathrm{C}\right)\end{array}$ & $\begin{array}{l}23.8 \\
28.4 \\
29.0\end{array}$ & $\begin{array}{l}2.396 \\
2.507 \\
2.521\end{array}$ & 2.475 & 0.068 \\
\hline A3 & $\begin{array}{l}\text { Oven }\left(40^{\circ} \mathrm{C}\right) \text {, } \\
30 \mathrm{~min}\end{array}$ & $\begin{array}{l}56.6 \\
59.0 \\
60.3\end{array}$ & $\begin{array}{l}3.187 \\
3.245 \\
3.276\end{array}$ & 3.236 & 0.045 \\
\hline A4 & $\begin{array}{l}\text { Oven }\left(40^{\circ} \mathrm{C}\right) \text {, } \\
60 \mathrm{~min}\end{array}$ & $\begin{array}{l}199.1 \\
148.8 \\
166.5\end{array}$ & $\begin{array}{l}6.622 \\
5.409 \\
5.836\end{array}$ & 5.956 & 0.615 \\
\hline
\end{tabular}

SD: Standard deviation, BPA: Bisphenol A

optimized was the carrier gas flow rate. The present results showed that a $1.0-\mathrm{mL} / \mathrm{min}$ gas flow rate was able to shorten the retention time, while still yielding high resolution and good column efficiency (Table 3). The results also show that a faster gas flow rate shortened the peak retention time of the compound. On the other hand, the $1.2-\mathrm{mL} / \mathrm{min}$ gas flow rate was not considered to be optimal because despite having the shortest retention time, the resulting resolution was poor.

Following optimization of GC-FID analysis conditions, a system compatibility test was performed to ensure the results obtained were valid despite possible variations. Six repeated injections of $15 \mu \mathrm{g} / \mathrm{mL}$ standard BPA solution produced an average of 367,935.353 theoretical plates, 0.0819 average HETP, 147.405 average resolution, 0.809 average tailing factor, and $0.554 \%$ CV (Table 4). Analysis of the BPA calibration curve produced a regression line equation of $y=41.485 x-75.602$ with a correlation coefficient of 0.99983 , meaning high linearity. The standard deviation and $\% \mathrm{CV}$ of the function were 0.0525 and $0.007 \%$, respectively. Thus, the present results showed good system compatibility and could be used for quantitative analysis of compounds. Interestingly, while the LOD $(0.287 \mu \mathrm{g} / \mathrm{mL})$ and LOQ $(0.956 \mu \mathrm{g} / \mathrm{mL})$ for the standard BPA solution were acceptable (Table 5), these values were greater than those reported by Farajzadeh et al., (LOD, $16 \mathrm{ng} / \mathrm{mL}$ and LOQ and $48 \mathrm{ng} / \mathrm{mL}$ ) and Zuo and Zhuo (LOD, $36.4 \mathrm{ng} / \mathrm{kg}$ ) for BPA by GC-FID [11,12]. This indicates that the present analytical method is less sensitive. This may be due to differences in sample preparation methods, column type, column temperatures, and carrier gas flow rates.
The selectivity test was performed to ascertain whether there was any disturbance/interference around BPA retention time on the chromatogram. Injection of the sample matrix solution under optimal analysis conditions did not produce any signal interference at the BPA retention time (9.883 $\mathrm{min}$ ). However, peaks representing other compound appear to flank that of BPA, suggesting the sample matrix contains a mixture of compounds, which could affect the selectivity.

Accuracy was determined by calculating the percent recovery using a standard addition method. Resultant BPA levels produced were reduced first with the sample level, then compared with the levels added to the sample solution (actual level) (1.2 [EN] meaning unclear. Please clarify). The percent recovery for $\mathrm{mg} / \mathrm{mL}$ concentrations should range from $80 \%$ to $120 \%$ for the method to be considered accurate. The average percent BPA recovery from samples containing an additional 2,4 , and $6 \mu \mathrm{g} / \mathrm{mL}$ of BPA was $102.93 \%$, $97.19 \%$, and $94.42 \%$, respectively, indicating the analysis method was accurate. Precision was determined by calculating the \% CV from six replicates runs at each standard addition concentration. The data are considered precise when a method produces a $\% \mathrm{CV} \leq 5 \%$. Standard addition of 2,4 , and $6 \mu \mathrm{g} / \mathrm{mL}$ BPA produced $\% \mathrm{CV}$ values of $3.24 \%$, $1.23 \%$, and $0.79 \%$, respectively, indicating the current results and, therefore, method, were precise.

Three different types of canned food samples underwent four different storage treatments (refrigerator $\left[4-8^{\circ} \mathrm{C}\right]: \mathrm{A} 1, \mathrm{~B} 1$, and $\mathrm{C} 1$; room temperature 
[25-30 $\left.{ }^{\circ} \mathrm{C}\right]$ : $\mathrm{A} 2$, B2, and $\mathrm{C} 2$; oven $\left[40^{\circ} \mathrm{C}\right]$ for 30 min: $\mathrm{A} 3, \mathrm{~B} 3$, and $\mathrm{C} 3$; and oven $\left[40^{\circ} \mathrm{C}\right]$ for $\left.60 \mathrm{~min}: \mathrm{A} 4, \mathrm{~B} 4, \mathrm{C} 4\right)$ to determine their effect on BPA migration rates into food. Ethyl acetate was used to extract BPA from food samples because its polarity is similar to that of BPA. Determination of BPA levels was done by plotting the peak BPA area with the linear regression equation of the BPA calibration curve. The present results revealed that all Group A (A1-A4) samples were positive for BPA contamination, with levels exceeding those recommended by the Indonesian National Drug and Food Control Agency (0.6 ppm). Interestingly, those samples stored at $4-8^{\circ} \mathrm{C}$ had significantly lower BPA contamination levels than those stored at higher temperature. However, none of the samples from Groups B or C had detectable levels of BPA. Using the lowest BPA level detected in the canned food samples was $2.242 \mu \mathrm{g} / \mathrm{mL}$ as a baseline, $200 \mathrm{~g}$ of canned food would theoretically contain $448.4 \mu \mathrm{g} / \mathrm{mg}$. If a $50-\mathrm{kg}$ human consumed $200 \mathrm{~g}$ of canned food daily, then the total BPA consumed daily would be $8.968 \mu \mathrm{g} / \mathrm{kg}$ of body weight, which greatly exceeds the $5 \mu \mathrm{g} / \mathrm{kg}$ body weight minimum tolerated dose/day according to the European Food Safety Authority (2014).

\section{CONCLUSION}

The current study designed and optimized GC-FID conditions for analysis of BPA in canned food samples. Using a gradually increasing column temperature $\left(150-260^{\circ} \mathrm{C}\right.$ in $10^{\circ} \mathrm{C} / \mathrm{min}$ increments), $3.0 \mu \mathrm{L}$ injection volume, $1.0 \mathrm{~mL} / \mathrm{min}$ gas flow rate, and $280^{\circ} \mathrm{C}$ injector and $300^{\circ} \mathrm{C}$ detector temperatures, the present BPA analysis method met requirements for system compatibility, selectivity, detection (LOD, $0.287 \mu \mathrm{g} / \mathrm{mL}$ ), quantitation (LOQ $0.956 \mu \mathrm{g} / \mathrm{mL}$ ), accuracy, and precision. Overall, higher storage temperatures and durations affected the level of BPA that migrated into the canned food samples.

\section{CONFLICTS OF INTEREST}

The authors declare that they have no conflicts of interest.

\section{REFERENCES}

1. Food and Drug Supervisory Agency of the Republic of Indonesia. Bisphenol A (BPA) on Food Packaging. Jakarta: Food and Drug Supervisory Agency of the Republic of Indonesia; 2014.

2. U.S Department of Health and Human Sciences. NTP-CERHR Monograph on the Potential Human Reproductive and Developmental Effects of bisphenol A. North Carolina: US State U.S Department of Health and Human Sciences; 2008.

3. Rykowska I, Wasiak W. Properties, threats, and methods of analysis of bisphenol A and its derivatives. Acta Chromatogr 2006;16:7-27.

4. Shrinithivihahshini N, Mahamuni D, Praveen N. Bisphenol A migration study in baby feeding bottles of selected brands available in the Indian market. Curr Sci 2014;25:1081-4.

5. Dutta M, Paul G. Bisphenol A dose-and time-dependently induces oxidative stress in rat liver mitochondria vivo. Asian J Pharm Clin Res 2018;11:98-105.

6. Indonesian Ministry of Trade. Indonesian Production and TradeIndonesia Technical Requirements Information System (INATRIMS); 2017. Available from: http://www.inatrims.kemendag.go.id/id/product/ detail/produksi-dan-perdagangan-indonesia 925/?market=ar]. [Last accessed on 2017 Jan 23].

7. Poole CF. Ionization-based detectors for gas chromatography. J Chromatogr A 2015;1421:137-53.

8. Obreshkova D, Tsvetkova DD, Ivanov K. Simultaneous identification and determination of total content of aminoacids in food supplementstablets by gas chromatography. Asian J Pharm Clin Res 2012;5:57-68.

9. Preet R, Gupta RC. Determination of fatty acids in Solanum surattense burm.F. By using gas chromatography. Asian J Pharm Clin Res 2017; $10: 60-2$

10. Gandjar IG, Rohman A. Chemical Pharmacy Analysis. Yogyakarta: Pustaka Pelajar; 2007. p. 463-80.

11. Farajzadeh M,AbbaspourM,Mogaddam M, Ghorbanpour H. Determination of some synthetic phenolic antioxidants and bisphenol $\mathrm{A}$ in honey using dispersive liquid-liquid microextraction followed by gas chromatograhyflame ionization detection. Food Anal Methods 2015;8:20135-43.

12. Zuo Y, Zhu Z. Simultaneous identification and quantification of 4-cumylphenol, 2,4-bis-(dimethylbenzyl)phenol and bisphenol A in prawn Macrobrachium rosenbergii. Chemosphere 2014;107:447-53. 